\title{
UKM2 Chlorella sp. Strain Electricity Performance as Bio-anode under Different Light Wavelength in a Biophotovoltaic Cell
}

(Prestasi Elektrik Strain UKM2 Chlorella sp. sebagai Bio-anod di bawah Gelombang Cahaya Berbeza dalam Sel Biofotovoltan)

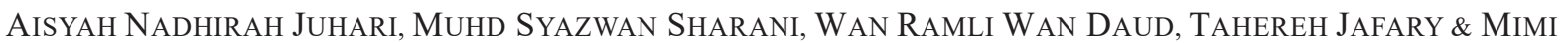 \\ HANI ABU BAKAR*
}

\begin{abstract}
A biophotovoltaic cell (BPV) is an electrobiochemical system that utilises a photosynthetic microorganism for instance is algae to trap sunlight energy and convert it into electricity. In this study, a local algae strain, UKM2 Chlorella sp. was grown in a BPV under different trophic conditions and light wavelengths. Once the acclimatisation phase succeeded, and biofilm formed, power generation by UKM2 algae at the autotrophic mode in synthetic Bold's Basal media (BBM) under white, blue and red lights were tested. Polarisation and power curves were generated at these different conditions to study the bioelectrochemical performance of the system. Later, the condition switched to algal mixotrophic nutritional mode, with palm oil mill effluent (POME) as substrate. Maximum power generation obtained when using UKM2 in BBM under red light where a power density of $1.19 \pm 0.16 \mathrm{~W} / \mathrm{m}^{3}$ was obtained at $25.74 \pm 3.89$ $\mathrm{A} / \mathrm{m}^{3}$ current density, while the open circuit voltage OCV reached $226.08 \pm 8.71 \mathrm{mV}$. UKM2 in POME under blue light recorded maximum power density of $0.85 \pm 0.18 \mathrm{~W} / \mathrm{m}^{3}$ at current density of $16.75 \pm 3.54 \mathrm{~A} / \mathrm{m}^{3}$, while the OCV reached $214.05 \pm 23.82 \mathrm{mV}$. Chemical oxygen demand (COD) removal reached an efficiency of 35.93\%, indicating the ability of wastewater treatment and electricity generation in BPV at the same time
\end{abstract}

Keywords: Algae; bioelectricity; biophotovoltaic; monochromatic light

ABSTRAK

Sel biofotovoltan (BPV) ialah satu sistem elektrobiokimia yang menggunakan mikroorganisma fotosintetik seperti alga untuk memerangkap tenaga cahaya matahari dan menukarkannya kepada elektrik. Dalam kajian ini, UKM2 Chlorella sp. iaitu strain alga tempatan yang ditempatkan di dalam BPV yang berbeza keadaan trofik dan gelombang cahaya. Apabila fasa aklimatisasi telah berjaya dan biofilem telah terhasil, kuasa tenaga yang telah dihasilkan oleh alga UKM2 dalam mod autotrofik sintetik Bolds's Basal Media (BBM) di bawah cahaya putih, biru, dan merah telah diuji. Lengkungan polarisasi dan lengkungan kuasa telah dihasilkan bagi keadaan yang berbeza-beza ini adalah untuk mengkaji pencapaian bioelektrokimia sistem tersebut. Setelah itu, keadaan tersebut diubah kepada alga mod campuran trofik nutrisi, dengan menggunakan sisa efluen minyak kelapa sawit sebagai substrat. Kuasa maksimum yang dihasilkan diperoleh menggunakan UKM2 di dalam BBM di bawah cahaya merah dengan ketumpatan kuasa sebanyak $1.19 \pm 0.16 \mathrm{~W} / \mathrm{m}^{3}$ telah diperoleh pada ketumpatan arus $16.75 \pm 3.54 \mathrm{~A} / \mathrm{m}^{3}$, manakala OCV pula mencecah sebanyak $226.08 \pm 8.71 \mathrm{mV}$. Permintaan kimia oksigen (COD) yang dibuang mencapai tahap keefisienan sebanyak 35.93\%, yang menunjukkan keupayaan untuk merawat sisa air buangan dan penghasilan elektrik pada BPV dalam pada masa yang sama.

Kata kunci: Alga; bioelektrik; biofotovoltan; cahaya monokromatik

\section{INTRODUCTION}

World energy demand will be experiencing high surge attributes to the upbeat industrial revolution and population growth. By the year 2040, world energy demand expected to rise to almost $30 \%$ from 575 quadrillion BTU in 2015 (EIA 2017). Currently, 91\% of world energy supply is from non-renewable resources, mainly fossil fuels
(Jones \& Warner 2016). The problems associated with the reliance on fossil fuels for energy supply are its rising price, the release of greenhouse gas emissions and its risk of depletion. Researchers hence have focused on greener and cleaner technologies for energy production in the future like solar, hydro-energy, biomass and wind power, which are renewable. However, each form of renewable energy 
is associated with a different problem such as expensive semiconductors for solar, destruction of habitat through hydro-energy, crop competition with biomass and unsteady weather for wind (Jones \& Warner 2016).

A fuel cell is an emerging technology in the field of clean energy production due to its absence of combustion and minimal pollution (Jafary et al. 2018; USGS 2018). A branch of the fuel cell, microbial fuel cell (MFC) mainly is being deeply explored for electricity production. An MFC consists of an anode and a cathode in a single unit whereby a living microorganism used as biocatalyst at the anode. The microorganism oxidises substrates in the anode chamber to liberate electrons. These electrons will travel to the cathode via an external circuit, thus generating power (while releasing $\mathrm{CO}_{2}$ in the anode chamber (Daud et al. 2018; Shamsuddin et al. 2018). At the cathode, an electron acceptor such as oxygen would accept the electrons and become reduced to water (Rusli et al. 2018). Wastewater is usually used as an organic substrate for microorganism at the anode, consequently coupled with wastewater treatment (Rahimnejad et al. 2014).

A biophotovoltaic (BPV) cell has a similar setup as that of the MFC. The difference lies when the BPV utilises anoxygenic photosynthetic microorganism such as the algae or cyanobacteria at the anode (McCormick et al. 2014). During photosynthesis, the photosynthetic microorganism generates electrons through water photolysis to produce oxygen at the anode (Dolai 2016; Ucar et al. 2017) and later reduces to water at the cathode. Therefore, BPV deems as more carbon-neutral than MFC for not requiring a continuous supply of organic substrates (McCormick et al. 2014). Studies of BPV utilising algae focuses on the following species: Chlorella vulgaris, Chlamydomonas reinhardtii, and Dunaliella tertioelecta with most studies utilising Chlorella vulgaris as the biocatalyst. They reported that Dunaliella tertioelecta achieved higher power output $\left(7 \mathrm{~mW} / \mathrm{m}^{2}\right)$ compared to Chlorella vulgaris $\left(0.45 \mathrm{~mW} / \mathrm{m}^{2}\right)$; however, Chlorella vulgaris (Thong et al. 2019) was far superior in terms of biomass density and biofilm attachment on the anode (McCormick et al. 2011). In an open-air cathode BPV, Chlorella vulgaris achieved $0.014 \mathrm{~mW} / \mathrm{m}^{2}$ of power generation in autotrophic conditions (De Caprariis et al. 2014). Up until now, limited information discusses on algal electricity generation in mixotrophic growth, combining both autotrophic and heterotrophic modes of growth $(\mathrm{Ng}$ et al. 2018; Saar et al. 2018). Algae is a microorganism that can utilise both modes of growth, as seen in studies involving algal wastewater treatment (Baicha 2016). Light intensity and type of light exposed to algae in BPV also has an impact on its electricity generation (Anderson et al. 2016). Algal contains chlorophyll and chlorophyll $\mathrm{b}$, both of which are light-harvesting pigments that are sensitive to red and blue lights. A report shows that algal appears growing under red and blue lights (Singh \& Singh 2015). In a study involving Chlorella vulgaris in a BPV with domestic wastewater, red light had the best impact on algae growth and simultaneously, the current generation (Yan et al. 2013).

The purpose of this research was to compare the performance of Chlorella vulgaris as a catalyst in BPV when in autotrophic and mixotrophic conditions and to determine the best monochromatic light for algal bioelectricity generation in the BPV. Therefore, this study highlights the capability of the algae species to produce clean electrical energy through BPV system while complementing the UKM2 Chlorella sp. application in wastewater treatment (Hariz et al. 2019; Hazman et al. 2018).

\section{MATERIALS AND METHODS}

\section{MEDIUM AND CULTIVATION OF MICROALGAE}

UKM2 Chlorella sp., a local microalgae strain isolated from palm oil mill effluent (POME) was selected for this study, and it was obtained from Carbon Capture Laboratory of Faculty of Engineering and Build, Universiti Kebangsaan Malaysia (UKM). UKM2 was cultivated in two different media; Bold's Basal Media (BBM) for autotrophic and POME for mixotrophic growth study. The compositions for both media were as provided in Tables 1 and 2 . The cell cultivation was using a setup, as shown in Figure 1 , at $25^{\circ} \mathrm{C}$ and under $24 \mathrm{~h}$ exposure to a fluorescent lamp. UKM2 was transferred to the BPV once it reached the exponential growth phase.

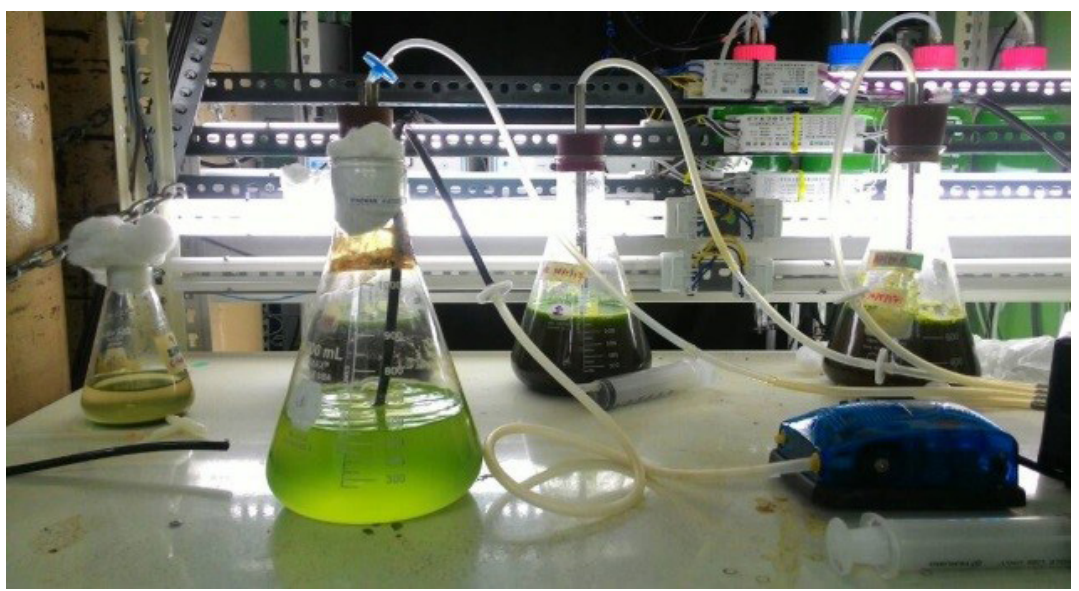

FIGURE 1. UKM2 cultivation condition 


\section{LIGHT SOURCE}

LED USB strip lights (Ledener, Canada) capable of emitting red, green, blue, and white light through a remote, was used as the light source for UKM2. White light (wavelength of $390-700 \mathrm{~nm}$ ) was used during the acclimatisation phase. However, either blue (wavelength of 450 - $495 \mathrm{~nm}$ ) or red light (wavelength of $620-750 \mathrm{~nm}$ ) was applied during further parameter testing. The LED strips taped to the wall of a black box containing the BPV cells. The cells were placed at about $1 \mathrm{~cm}$ distance from the wall. The distance provides the UKM2 in the anode with a light source of 1000 lux.

TABLE 1. Composition of Bold's Basal Media (BBM)

\begin{tabular}{|c|c|c|}
\hline Solution & Component & Quantity (g) \\
\hline \multirow[t]{7}{*}{ Main solution (in $10 \mathrm{~mL}$ ) } & $\mathrm{NaNO}_{3}$ & 0.25 \\
\hline & $\mathrm{CaCl}_{2} \cdot 2 \mathrm{H}_{2} \mathrm{O}$ & 0.025 \\
\hline & $\mathrm{MgSO}_{4} \cdot 7 \mathrm{H}_{2} \mathrm{O}$ & 0.075 \\
\hline & $\mathrm{K}_{2} \mathrm{HPO}_{4}$ & 0.075 \\
\hline & $\mathrm{KH}_{2} \mathrm{PO}_{4}$ & 0.175 \\
\hline & $\mathrm{NaCl}$ & 0.025 \\
\hline & $\mathrm{H}_{3} \mathrm{BO}_{3}$ (in $1 \mathrm{~mL}$ ) & 0.01142 \\
\hline \multirow[t]{2}{*}{ EDTA solution (in $1 \mathrm{~mL}$ ) } & EDTA & 50 \\
\hline & $\mathrm{KOH}$ & 31 \\
\hline \multirow[t]{3}{*}{ Acidified metal solution (in $1 \mathrm{~mL}$ ) } & $\mathrm{FeSO}_{4} \cdot 7 \mathrm{H}_{2} \mathrm{O}$ & 0.498 \\
\hline & $\mathrm{H}_{2} \mathrm{SO}_{4}(96 \%)$ & $0.1 \mathrm{~mL}$ \\
\hline & $\mathrm{ZnSO}_{4} \cdot 7 \mathrm{H}_{2} \mathrm{O}$ & 8.82 \\
\hline \multirow[t]{4}{*}{ Trace solution (in $1 \mathrm{~mL}$ ) } & $\mathrm{MnCl}_{2} \cdot 4 \mathrm{H}_{2} \mathrm{O}$ & 1.44 \\
\hline & $\mathrm{MoO}_{3}$ & 0.71 \\
\hline & $\mathrm{CuSO}_{4} .5 \mathrm{H}_{2} \mathrm{O}$ & 1.57 \\
\hline & $\mathrm{Co}\left(\mathrm{NO}_{3}\right)_{2} \cdot 6 \mathrm{H}_{2} \mathrm{O}$ & 0.49 \\
\hline
\end{tabular}

TABLE 2. Composition of palm oil mill effluent at $\mathrm{pH} 7.5$

\begin{tabular}{|c|c|}
\hline Parameter & Value $(\mathrm{mg} / \mathrm{L})$ \\
\hline $\mathrm{BOD}_{5}$ & 809 \\
\hline COD & 2370 \\
\hline $\mathrm{TN}$ & 97.22 \\
\hline $\mathrm{NH}_{3}-\mathrm{N}$ & 197.5 \\
\hline Oil \& Grease & 0.63 \\
\hline Copper $(\mathrm{Cu})$ & 0.08 \\
\hline Zinc (Zn) & 0.04 \\
\hline Cadmium (Cd) & 0.011 \\
\hline Phosphorus (P) & 8.734 \\
\hline
\end{tabular}




\section{BIOPHOTOVOLTAIC CELL CONSTRUCTION AND INNOCULATION}

A double-chambered BPV constructed from a light penetrable 'Perspex' material with a total volume of $0.1 \mathrm{~L}$ in each chamber. Long graphite brushes of $7.5 \mathrm{~cm}$ twisted around titanium wires were used as the anodes and cathodes while Nafion cationic exchange membranes (CEM) placed in between the two chambers. Each open-end anode chamber sealed with a glass panel $(96 \times 56 \times 2 \mathrm{~mm})$ to allow penetration of the light source.

At the beginning of the experiments, the anolyte volume filled with 50\% UKM2 Chlorella sp. culture and $50 \%$ of BBM. Potassium hexacyanoferrate (III) together with potassium phosphate buffer at $100 \mathrm{mM}$ became the catholyte. The distance between the anode and cathode electrodes was about $5 \mathrm{~cm}$. The BPV components and configuration is, as shown in Figure 2. The anolytes were agitated at a rate of $400 \mathrm{rpm}$. The voltage across the electrodes was monitored continuously by an online data acquisition system (Keithley 2700 Multimeter, Keithley, America). All experiments ran in triplicates.

For the first 20 days, UKM2 in the BPVs were exposed to constant $24 \mathrm{~h}$ illumination of 1000 lux white light (as control). An external load of $1000 \mathrm{ohm}$ applied to each cell, and the voltage data from each cell recorded continuously. Fresh BBM media replaced half of BBM anolyte once the voltage dropped to $45-60 \mathrm{mV}$ at each cycle. The anodic chamber was sparged with nitrogen gas by bubbling for $30 \mathrm{~s}$ to displace the oxygen produced by algal photosynthesis. Once stable voltage cycles over time were observed, the algae considered as successfully attached to the surface of the electrodes, forming the biofilm.

(b)
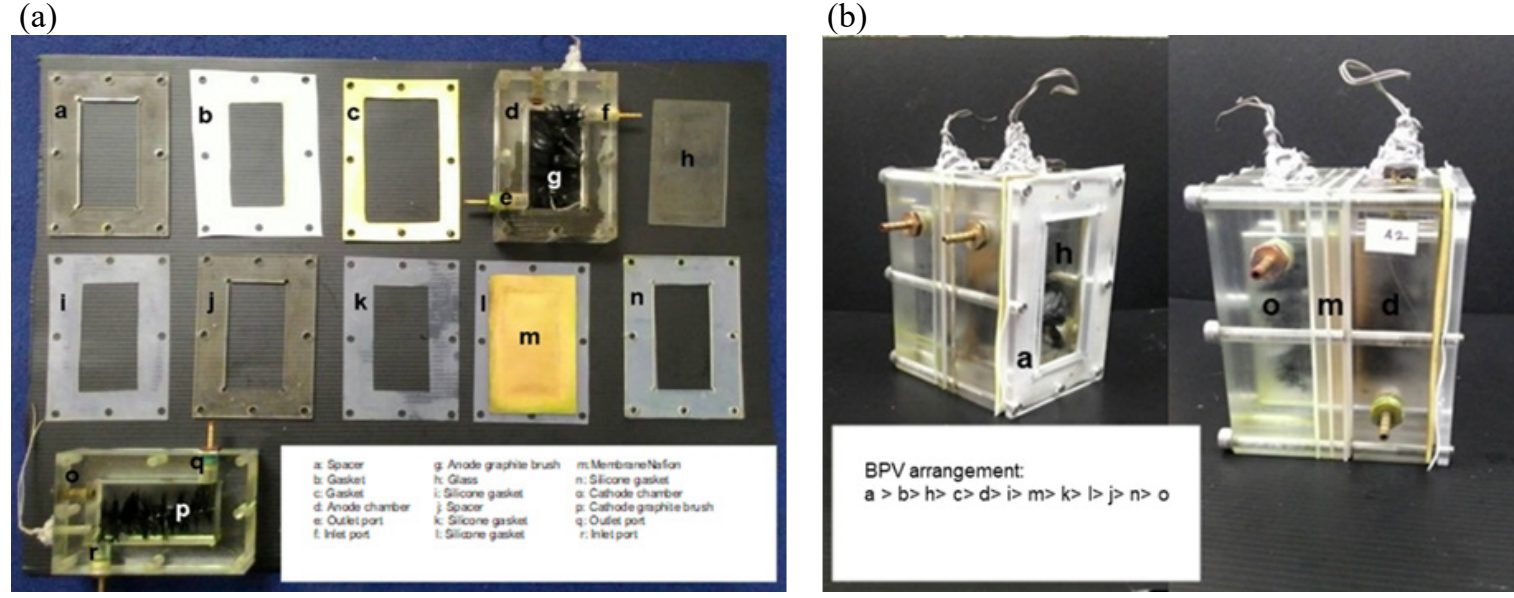

FIGURE 2. BPV components (a) and configuration (b)

\section{ALGAE EXPOSURE TO MONOCHROMATIC LIGHT}

Once the biofilm formed, the LED light strip then switched to blue colour and the cells were exposed to $24 \mathrm{~h}$ blue light at 1000 lux over four days. Electrogenic activity assessment was performed at the end of the fourth day to test the performance of the cells under the blue light condition. The same procedure repeated when operated in red light. About $50 \%$ of BBM media from the anode was replaced with POME media. The replacement of media was after analyzing the performance of the cells under the illumination of blue and red lights. The POME media was centrifuged twice at $8000 \mathrm{rpm}$ for $10 \mathrm{~min}$ prior to use. Later, the POME was autoclaved at $121^{\circ} \mathrm{C}$ to ensure the elimination of microorganism in the POME. The cells again exposed to the blue and red lights, and their electrogenic activities recorded.

\section{ELECTROGENIC ACTIVITY ASSESSMENT}

For the electrogenic assessment, open-circuit voltage $(\mathrm{OCV})$, closed-circuit voltage $(\mathrm{CCV})$ and current at 1000 $\Omega$ external load were measured using the data acquisition system. Polarisation and power curves were generated through linear sweep voltammetry technique using the Autolab Metrohm potentiostat (Metrohm, Sweden), with scan rate of $1 \mathrm{mV} / \mathrm{s}$ and range from $0 \mathrm{mV}$ to system open circuit potential detected by the measuring instrument. The densities normalised according to the volume of the anolyte, which was $0.1 \mathrm{~L}$. Each time the media was replaced, $\mathrm{COD}, \mathrm{pH}$, and dissolved oxygen (DO) readings were taken from the residual media. The COD measured by using high range COD vials (Hach, USA) according to the manufacturer's manual while the DO 
was measured using the Multiparameter HI2040-01 DO Meter (Hanna Instruments, USA). Cyclic voltammetry analysis was conducted on the anolytes and anodes using the potentiostat with $\mathrm{Ag} / \mathrm{AgCl}$ as a reference electrode. The potential scan range was between -1 and $0.1 \mathrm{~V}$ at a scan rate of $0.025 \mathrm{~V} / \mathrm{s}$. The Columbic efficiency (CE) of the cells were calculated using the formula used by Rodrigues (2014):

$$
C E=\frac{I \cdot t \cdot M}{n \cdot F \cdot v A n \cdot \Delta C O D}
$$

where I is current (A); $\mathrm{t}$ is batch time (h); M is molecular weight of substrate in media $(\mathrm{g} / \mathrm{mol})$; $\mathrm{n}$ is number of electrons exchanged per mole of oxygen; $\mathrm{F}$ is $96,485 \mathrm{C} /$ mol (Faraday's constant); vAn is the anolyte volume and is the change of COD during that batch time.

\section{ALGAL BIOFILM IMAGING}

At the end of the study, a $0.5 \mathrm{~cm}$ cut of the graphite brush was extracted from the system for imaging under Variable Pressure Scanning Electron Microscope (VPSEM) LEO1450VP (Zeiss, German). Before the graphite brush cut-out analysed under VPSEM, it was immersed inside ethanol of different concentration for $10 \mathrm{~min}$ each: $30,50,70,80,90$, and $100 \%$. The sample was dried again via a critical point dryer before viewing using VPSEM.

\section{RESULTS AND DISCUSSION}

\section{AUTOTROPHIC GROWTH: ELECTROGENIC ACTIVITY OF ALGAE DURING ACCLIMATISATION PHASE}

During the acclimatisation phase, $\mathrm{CCV}$ and current generated from the cells under an external load of 1000 ohm were recorded and plotted in Figure 3. Each cycle indicates the replacement of BBM media in the anolyte and hexacyanoferrate in the cathode. All cells reached a homeostatic state from the acclimatisation phase by the $12^{\text {th }}$ day (at the end of Cycle 3 ) and a stable pattern of electricity generation. The acclimatisation period is slightly longer than that achieved by De Caprariis et al. (2014) who obtained acclimatisation of Chlorella vulgaris within six days, however, with a different setup and media for algae growth. The voltage recorded increased each time the media was replaced, indicating the ability of UKM2 adapting to the environment. In Cycle 1, carbon dioxide supplied to all systems as a carbon source for oxygenic algal photosynthesis; however, a variation of voltage recorded was very small up to $9 \pm 7 \mathrm{mV}$. This voltage could also reflect noise or variation from the data logger. The peak voltage values recorded were much lower than that obtained from another study which was $50 \mathrm{mV}$ under an external load of $100 \Omega$ (Subhash et al. 2013) with mixed algae culture in sewage water at the anode. In Cycle 2, an increased concentration of BBM only resulted in a decline of power (Ghoreyshi et al. 2011). The concentration used in Cycle 3 later was doubled from Cycle 2 and managed to increase the average voltage up to $63 \%$ from Cycle 1 . At the end of Cycle 3, all cells indicated a steady pattern of voltage raised and declined during media replenishment, indicating a stable UKM2 community development in the anode. However, the voltage values in all systems need to be standardised in order to proceed with the next parameter.

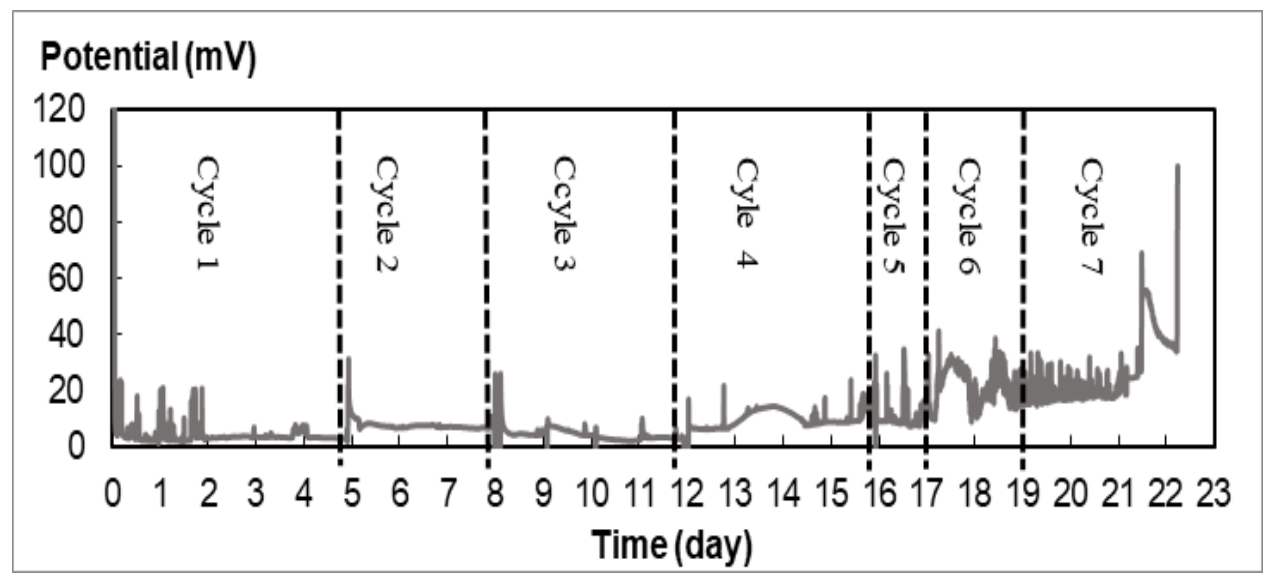

FIGURE 3. Closed circuit voltage of UKM2 Chlorella sp. under $1000 \Omega$ resistance 
The deviation in power production among the replicate was due to one of the anodes had healthy algae growth, that appeared through the bright green colour. The healthy growth could contribute to its low CCV values. McCormick et al. (2011) and Saratale et al. (2017) stated that oxygen supplied by algae through its oxygenic photosynthesis develops a limitation within the system that in turn, causes a low power generation. Thus, in succeeding cycles, nitrogen gas had to be supplied to the anode for one minute at $60 \mathrm{~cm}^{3} / \mathrm{min}$ in all cells for each feeding.

Sparging carbon dioxide for almost a minute into the BPV systems during each feeding time, might not be sufficient. There was a possibility that the carbon dioxide did not dissolve well in the anolyte, and little might have reached UKM2 for photosynthesis. Hence, in Cycle 6, sodium bicarbonate was chosen as an inorganic carbon source substitute as it could dissolve in the anolyte better than carbon dioxide. Sodium bicarbonate can increase algal biomass (Mokashi et al. 2016). In Cycle 7 , the cells achieved peak voltages in the range of 40-53 $\mathrm{mV}$ and considered as a standardised and ready for the next testing parameter.

\section{AUTOTROPHIC GROWTH: ELECTROGENIC ACTIVITY OF ALGAE UNDER DIFFERENT MONOCHROMATIC LIGHT}

The power and polarisation curves were generated at the end of 26 days acclimatisation phase under white light. Then, the light was switched to blue light for four days, followed by a red light for another four days. Polarisation and power curves were generated at the end of each period. The internal resistance of the cell was determined by taking the linear gradients of the polarisation curves (De Caprariis et al. 2014; Logan 2008). A maximum power density of $1.19 \pm 0.16 \mathrm{~W} / \mathrm{m}^{3}$ was acquired when UKM2 in BBM exposed to red light, which is $29 \%$ more compared to white light exposure $\left(0.85 \pm 0.02 \mathrm{~W} / \mathrm{m}^{3}\right)$ and $26 \%$ more compared to blue light $\left(0.88 \pm 0.19 \mathrm{~W} / \mathrm{m}^{3}\right)$ exposure (Figure 4). These results comply with the superior current production and internal resistance shown by the red light followed by the blue and the white lights (Table 3). Through observation, UKM2 in BBM media under autotrophic growth showed maximum peak power density when placed under red light, followed by blue light and white light (Figure 4). The same result obtained by Lan et al. (2013) when exposing Chlamydomonas reindhartii to a red light and McCormick et al. (2011) when Chlorella vulgaris was under red light, where improvement of power generation was recorded.

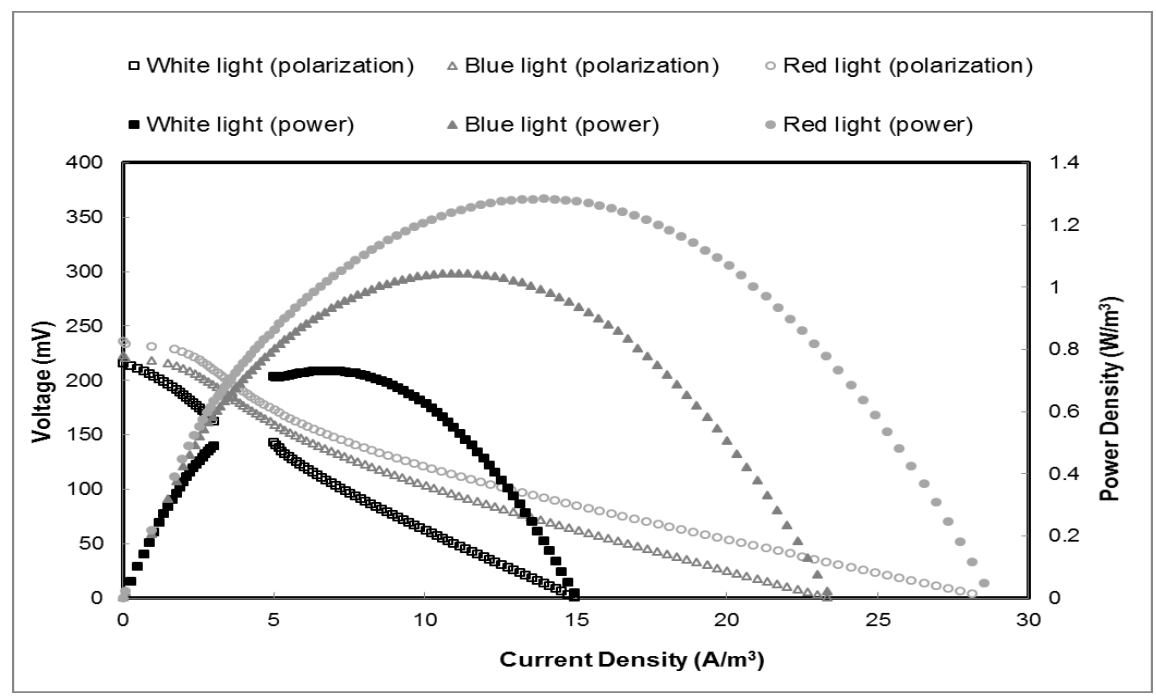

FIGURE 4. Power and polarization curves of UKM2 in BBM under white light, blue light and red light

Green algae, an oxygenic photosynthesis microorganism contains chloroplast in its cellular structure. Inside the chloroplast are two photosystems recognised as Photosystem I and Photosystem II, both of which contain chlorophyll and carotenoid pigments for light absorption (Lan et al. 2013). The maximum absorption peak for chlorophyll is at the red light wavelength while for carotenoid pigments is at the blue light wavelength. 
Exposure to either of these lights proven to increase the efficiency of photosynthesis, resulting in an overall better algal growth (Singh \& Singh 2015). The increase in photosynthetic efficiency indicates an improvement in electron generation, which leads to an improvement in electricity generation.
Since carotenoid pigments are secondary agents to photosynthesis/electron generation compared to chlorophyll; exposure to a red light, however, had shown to cause the highest power generation.

TABLE 3. Polarization and power summary for BPV under white, blue and red light in BBM

\begin{tabular}{lccc}
\hline \multicolumn{1}{c}{ Parameter } & White light & Blue light & Red light \\
\hline Maximum current density, $\mathrm{I}_{\max }\left(\mathrm{A} / \mathrm{m}^{3}\right)$ & $14.94 \pm 0.45$ & $19.02 \pm 3.48$ & $25.74 \pm 3.89$ \\
Open circuit voltage/OCV,$(\mathrm{mV})$ & $216.06 \pm 6.69$ & $214.44 \pm 23.89$ & $226.08 \pm 8.71$ \\
Internal resistance, $\mathrm{R}_{\text {int }}(\mathrm{ohm})$ & $148.29 \pm 0.50$ & $118.70 \pm 14.83$ & $96.25 \pm 9.80$ \\
\hline
\end{tabular}

The OCVs recorded when operating the BPVs in different lights showed blue light was $1 \%$ more than the white, while the red light was almost $5 \%$ more than the white (Table 3). The obtained OCVs in this study, however, was higher than Zou et al. (2009) (reported OCV up to $130 \mathrm{mV}$ ), which used an air-cathode reactor while much smaller than that reported by Jadhav et al. (2017) (reported up to $570 \mathrm{mV}$ ), which used clayware reactor as a separator with lower overpotential.

The DO profile presented in Figure 5 signifies an almost constant level of DO at $2.5-5 \mathrm{ppm}$, with no apparent rise in oxygen content. The low stable oxygen content is attributed to the purging of nitrogen to the anode chamber of all systems during feeding time to avoid the accumulation of photosynthetic oxygen from interrupting in power generation. The profile, however, shows a slight increase in $\mathrm{pH}$ over time due to intake of sodium bicarbonate in BBM algal autotrophic growth (Kim et al. 2014).

\section{MIXOTROPHIC GROWTH: ELECTROGENIC ACTIVITY OF ALGAE UNDER DIFFERENT MONOCHROMATIC LIGHT}

The experiment was repeated by switching UKM2 feeding mode from autotrophic to mixotrophic by changing the BBM media to POME and placing it under blue and red light for four days each. In mixotrophic growth, there was no apparent difference in power generation by UKM2 when using blue or red light. UKM2 in POME under both lights recorded a maximum power density of $0.85 \mathrm{~W} / \mathrm{m}^{3}$ (Table 4). A plausible explanation for the low power generation could be the anoxygenic mixotrophic feeding mode carried by UKM2 in POME. The anoxygenic environment created each time POME was replenished involving purging of nitrogen into the anode creating an oxygenpoor environment. Thus, UKM2 most likely switched to anoxygenic photosynthesis in this environment. In an autotrophic mode where algae would perform oxygenic photosynthesis, it would utilise photosystem I, photosystem II and the bf cytochrome complex in an electron transport chain that would generate oxygen in the end. However, in the anoxygenic photosynthesis process, green algae use the bacteriochlorophyll molecules to trap sunlight energy as an energy source, additionally using organic carbon or inorganic carbon such as carbon dioxide as electron source (Ng et al. 2018). The pigment molecules that capture the sunlight would direct it to bacteriochlorophyll a, and after a series of photochemical reactions, negative and positive charges penetrate through the membrane without the formation of oxygen. According to Connolly et al. (1982), the maximum absorption peak for bacteriochlorophyll is the light wavelength in the range of $300-400 \mathrm{~nm}$. Since blue light and red light are both out of these ranges, the exposure to either colour of the light was not able to increase the efficiency of anoxygenic photosynthesis by UKM2. Thus, there was no notable difference in power generation under these two lights. The red light, however, seems not compatible with mixotrophic growth. The internal resistance increased up to $86 \%$ with a standard error of the mean $(\sigma \mathrm{M})$ distribution increased up to $368 \%$ compared when in autotrophic growth (Tables $3 \&$ 4). The result agrees with the OCV, increased up to $235 \%$ of $\sigma \mathrm{M}$ in mixotrophic growth compared to autotrophic growth due to overpotential within the replicates. 


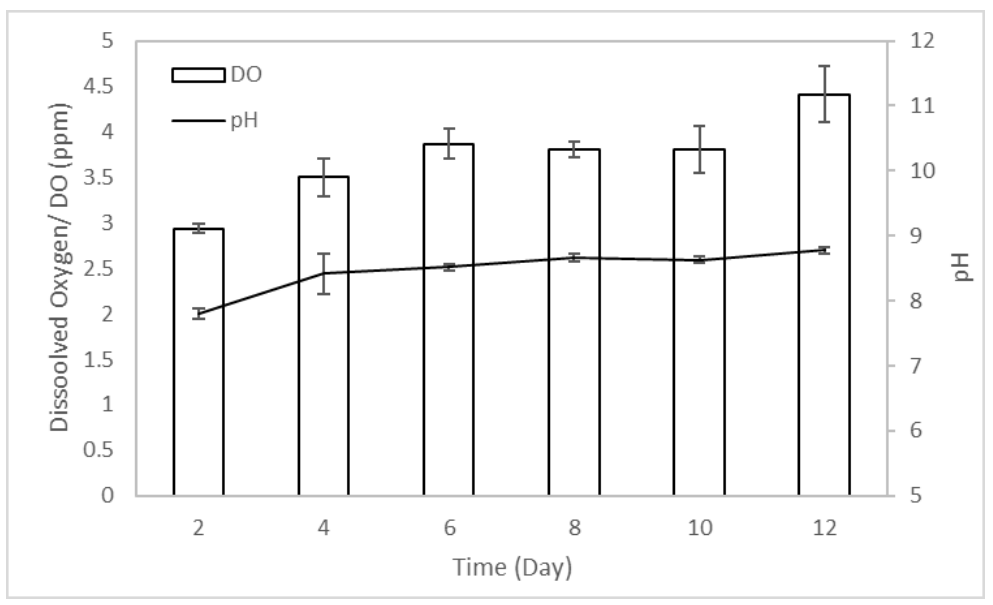

FIGURE 5. Dissolved oxygen and $\mathrm{pH}$ profile of UKM2 in BBM media

TABLE 4. Polarization and power curve summary for BPV under white, blue and red light in POME

\begin{tabular}{lcc}
\hline \multicolumn{1}{c}{ Parameter } & Blue light & Red light \\
\hline Maximum power density, Pmax (W/m3) & $0.85 \pm 0.03$ & $0.85 \pm 0.02$ \\
Maximum current density, Imax (A/m3) & $19.57 \pm 3.85$ & $16.75 \pm 3.54$ \\
Open circuit voltage/OCV, (mV) & $214.05 \pm 23.82$ & $322.16 \pm 29.19$ \\
Internal resistance, Rint $(\mathrm{ohm})$ & $111.06 \pm 18.35$ & $178.90 \pm 45.85$ \\
\hline
\end{tabular}

As time progressed, DO, and $\mathrm{pH}$ levels showed a declining trend (Figure 6). The result is related to the mixotrophic growth whereby oxygen was used as the final electron acceptor in the dark aerobic respiration process, resulting in the production of carbon dioxide. The carbon dioxide generation contributes to a more acidic environment, hence a lower $\mathrm{pH}$.

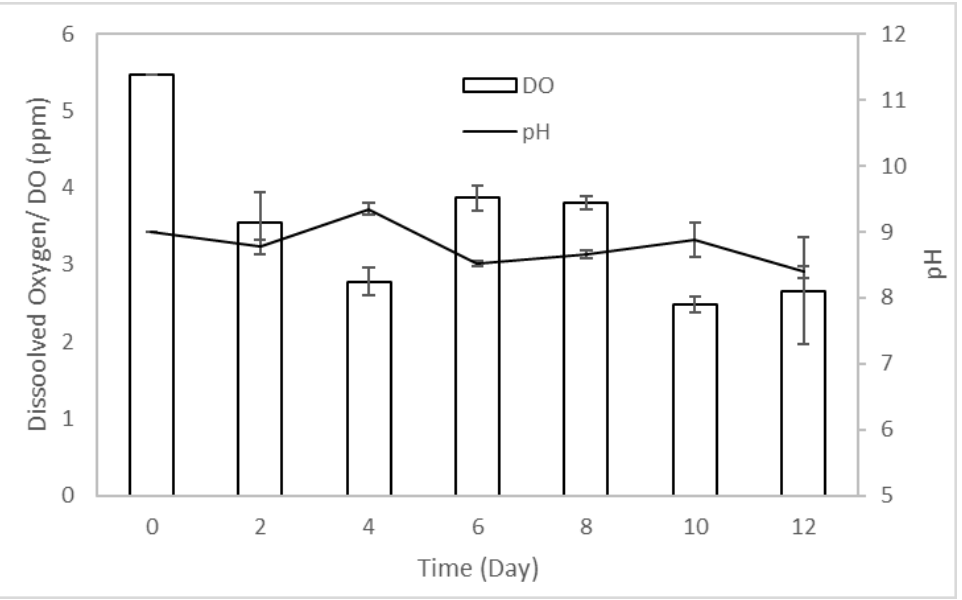

FIGURE 6. Dissolved oxygen and pH profiles of UKM2 in POME 
MIXOTROPHIC GROWTH: COD REDUCTION IN PALM OIL MILL EFFLUENT MEDIA

COD readings of the POME media was recorded before and after feeding it to UKM2 at the anode. As expected, a reduction of COD observed each time replacing the POME (Table 5). UKM2 utilised the organic carbon in its mixotrophic growth, which explains the COD reduction from the initial COD in the system, $2370 \mathrm{mg} / \mathrm{L}$. The COD results within the four days of operation at different light sources in the mixotrophic growth environment recorded the total COD reduction at blue light (106\%) compared to the red (38\%) (Table 5). The obtained results support the conundrum of the increased in overpotential of the mixotrophic growth BPV when operating under red light.

TABLE 5. COD reduction under POME anolyte in BPV by UKM2 Chlorella sp.

\begin{tabular}{|c|c|c|}
\hline Parameter & Blue light (mg/L) & Red light $(\mathrm{mg} / \mathrm{L})$ \\
\hline Day 2 & $905 \pm 18.72$ & \\
\hline Day 4 & $1323.67 \pm 21.67$ & \\
\hline Day 6 & & $1833.67 \pm 39.07$ \\
\hline Day 8 & & $2012 \pm 33.98$ \\
\hline
\end{tabular}

\section{MIXOTROPHIC GROWTH: COLUMBIC EFFICIENCY OF BPV}

$\mathrm{CE}$ of the system refers to the comparison of electrons generated as a result of substrate degradation in anolyte. The substrate degradation causes electrons to move to the anode and through the external circuit of a cell. The higher its CE value, the higher efficiency of electricity generation of that system (Rodrigues 2014). For POME, acetate became the calculation basis for substrate (Hariz \& Takriff 2017), and the following data was used in determining the CE using formula (1); where $M=59 \mathrm{~g} / \mathrm{mol}$, $\mathrm{n}=8$ electrons $/$ mole and $\mathrm{t}=48 \mathrm{~h}$. CE value was calculated for BPV under red and blue lights in POME (Table 6). A higher CE was obtained under blue light (30.36\%) when compared to red light $(25.98 \%)$. The recorded value is much higher than Cui et al. (2014) and Zhou et al. (2012); both of which utilised algae as bio-cathode. The results in this study agree that biofilm growth of UKM2 Chlorella sp. on graphite brush has formed well (Rodrigues 2014).

TABLE 6. Columbic efficiency of BPV under mixotrophic growth using UKM2 Chlorella sp.

\begin{tabular}{ccc}
\hline Parameter & Blue light & Red light \\
\hline Maximum current density (A/m $\left.{ }^{3}\right)$ & $19.57 \pm 3.85$ & $16.75 \pm 3.54$ \\
Coulumbic efficiency (CE) (\%) & 30.36 & 25.98 \\
\hline
\end{tabular}

\section{MIXOTROPHIC GROWTH: CYCLIC VOLTAMMETRY TEST ON BPV ANODE}

The $\mathrm{CV}$ result obtained for anodic biofilm shows a bulge at the current (current produced when electrode donates an electron towards the electrolytes) around voltage of -395 to $-195 \mathrm{mV}$ (vs SHE), which was absent for the system without biofilm. Referring to the standard reduction potential for a biological system, at $\mathrm{pH} 7$ and temperatures 
between $25-37^{\circ} \mathrm{C}$, the voltage recorded should refer to the reaction of -ketoglutarate towards carbon dioxide, proton, and electrons for citrate production, while b-type cytochrome in Chlorella nitrate reductase is $-168 \mathrm{mV}$ (Barber et al. 1987). As this system operated at a $\mathrm{pH}$ of 8 , it is unknown whether a similar reaction has occurred. However, VPSEM analysis performed was able to determine the presence of UKM2 biofilm on the anode.

Generally, for a CV test, a brush with biofilm layer on it will show a redox catalytic current value indicating the existence of oxidation-reduction reactions performed by algal biofilm layer. However, from Figure 7, it was observed that current from the anode of BPV with biofilm was lower than the one without biofilm (control) and vice versa with the current from the anode. This result signifies that for electrode biofilm in which CV performed insitu; it is easier for the electrode to donate its electrons towards surroundings. Small current from the anode means the existence of high electrolyte resistance to donate electrons towards the cathode.

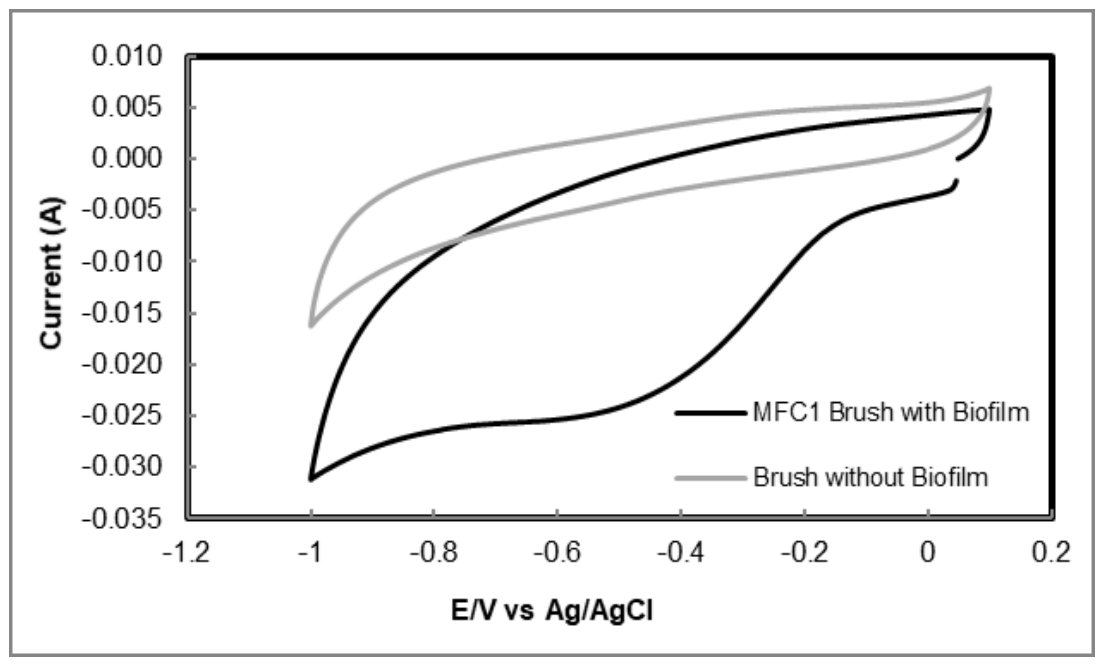

FIGURE 7. Cyclic voltammetry test of BPV

\section{MIXOTROPHIC GROWTH: COMPARISON OF ELECTRICITY GENERATION WITH OTHER STUDIES}

The results of this study were compared with those obtained from other studies (Table 7). However, the studies utilising microalgae in the anode of BPV using graphite brush is still lacking, and most researches would normalise the current generation obtained in their systems with the surface area of the electrode. However, in this study, the current and power obtained were normalised using the volume of anolyte in the BPV. The results then are compared with studies that utilised brush electrodes in their BPV and where the data was normalised using the volume of the reactor.

Table 7 shows that the power generation of UKM2 Chlorella sp. in this study is still low compared to other studies. However, the difference is because of other studies utilised algae as bio-cathode, while this study used algae as bio-anode. Therefore, electricity generation of microalgae in BPV relies entirely on the photosynthetic efficiency of algae compared to other conventional MFCs, which utilises non-photosynthetic bacteria for power. According to McCormick et al. (2011), the electron transfer ability of oxygenic photosynthetic microorganism is lower than the non-photosynthetic bacteria in MFCs. Besides, the accumulation of oxygen at the BPV anode due to photosynthesis contributes to low electricity generation as time passes. These factors, added with other factors like BPV design, may explain, why the power generated by UKM2 as bio-anode in this study was much lower than other systems that utilising algae as bio-cathode. 
TABLE 7. Comparison of electricity generation of UKM2 Chlorella sp. with other studies

\begin{tabular}{|c|c|c|c|c|c|}
\hline Parameter & This Study & Cui et al. (2014) & Zhou et al. (2012) & Wang et al. (2010) & $\mathrm{Ng}$ et al. (2014) \\
\hline Algae species & $\begin{array}{l}\text { UKM2 Chlorella } \\
\text { sp. }\end{array}$ & $\begin{array}{l}\text { Chlorella } \\
\text { vulgaris }\end{array}$ & Chlorella vulgaris & Chlorella vulgaris & $\begin{array}{l}\text { UMACC } 313 \\
\text { Chlorella sp. }\end{array}$ \\
\hline Type of cell & Double chamber & Double chamber & Double chamber & Double chamber & Single chamber \\
\hline Algae usage & Bio-cathode & Bio-cathode & Bio-cathode & Bio-cathode & Air-cathode \\
\hline Electrode & $\begin{array}{c}\text { Anode: Graphite } \\
\text { brush } \\
\text { Cathode: Graphite } \\
\text { brush }\end{array}$ & $\begin{array}{l}\text { Anode: Carbon } \\
\text { brush } \\
\text { Cathode: Carbon } \\
\text { cloth }\end{array}$ & $\begin{array}{l}\text { Anode: Carbon } \\
\text { felt } \\
\text { Cathode: Carbon } \\
\text { fibre cloth }\end{array}$ & $\begin{array}{l}\text { Anode: Carbon } \\
\text { brush } \\
\text { Cathode: Carbon } \\
\text { cloth }\end{array}$ & $\begin{array}{l}\text { Anode: Indium } \\
\text { tin oxide (ITO) } \\
\text { modified glass } \\
\text { Cathode: Platinum } \\
\text { coated glass }\end{array}$ \\
\hline Power density $\left(\mathrm{W} / \mathrm{m}^{3}\right)$ & 1.19 & 8.77 & 2.49 & $4.10-5.60$ & $0.29 \times 10^{-3} \mathrm{~W} / \mathrm{m}^{2}$ \\
\hline Current density $\left(\mathrm{A} / \mathrm{m}^{3}\right)$ & 25.74 & - & 7.9 & - & $5.35 \times 10^{-3} \mathrm{~A} / \mathrm{m}^{3}$ \\
\hline COD reduction $(\%)$ & 35.93 & - & 84.8 & - & - \\
\hline $\begin{array}{l}\text { Columbic efficiency, } \\
\text { CE }(\%)\end{array}$ & 28.17 & 6.5 & 9.40 & - & - \\
\hline
\end{tabular}

\section{ALGAL BIOFILM FORMATION ON ANODIC SURFACE}

The biofilm layer formation of UKM2 on anodic graphite brush was observed by comparing a small cut sample of graphite brush immersed in UKM2 culture to a clean graphite brush using VPSEM imaging. Figure 8 (a) shows the VPSEM images obtained under 5000× magnifications obtained for graphite brush cut samples, both clean and with UKM2 biofilm. Based on Figure 8(b), the graphite brush with the UKM2 biofilm, has clumps of microorganism on the surface of the brush. Figure 8 (b) especially shows the presence of spherical shape UKM2 cells forming a biofilm layer on the brush (Hariz \& Takriff 2017). (a)

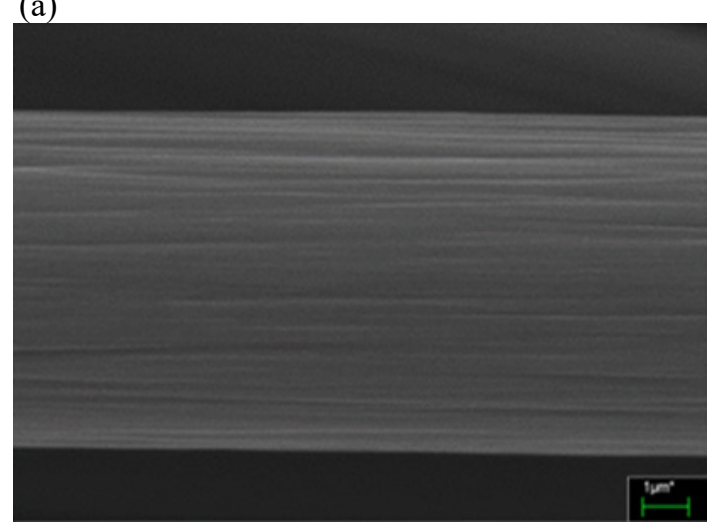

(b)

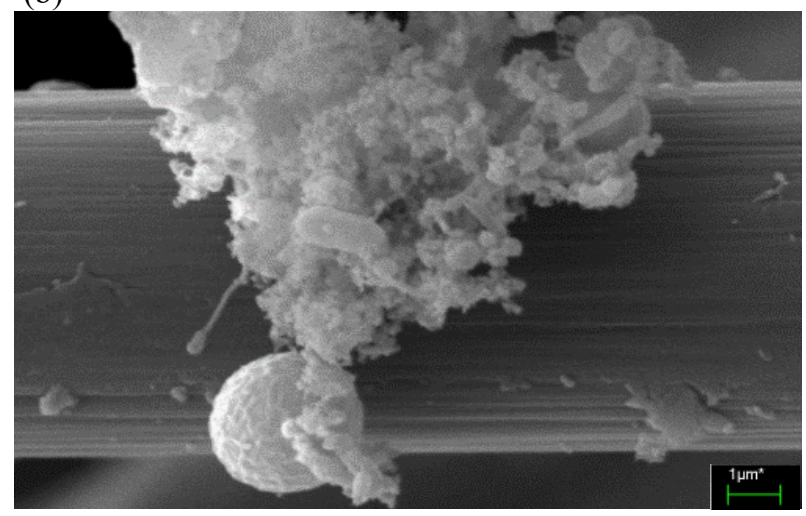

FIGURE 8. (a) Clean graphite brush and (b) graphite brush with UKM2 biolfilm (Image taken with VPSEM at magnification of $5000 \times$ ) 


\section{CONCLUSION}

In this study, UKM2 Chlorella sp. was grown in two media, which are BBM and POME for inoculation inside the BPV. UKM2 culture showed good growth in both media and showed quick adaptation in the environment and was able to enter the exponential phase almost immediately. Once UKM2 inoculum introduced into the BPV anode, on average UKM2 was able to acclimatise in 12 days. Afterwards, a stable electricity generation (rise and decline over time) observed each time replacement of a new media. Overall UKM2 showed maximum power generation when grown in BBM and placed under red light, whereby a power density of $1.19 \mathrm{~W} / \mathrm{m}^{3}$ obtained at a current density of $25.74 \mathrm{~A} / \mathrm{m}^{3}$. Although the results obtained are lower than other studies, this difference is attributed to the usage of algae as bio-cathode in the other studies compared to bio-anode used in this study. More research is necessary for optimising the power generation of algae in BPV due to its potential as a carbon-neutral energy source with wastewater treatment integration.

\section{ACKNOWLEDGEMENTS}

The authors appreciate the financial support offered by Universiti Kebangsaan Malaysia through several research grants (DIP-2018-014, GUP-2018-012 and GUP-2017-094) and analyses assistance by the Centre for Research and Instrumentation Management (CRIM) of Universiti Kebangsaan Malaysia and the Fuel Cell Institute of Universiti Kebangsaan Malaysia.

\section{REFERENCES}

Anderson, A., Laohavisit, A., Blaby, I.K., Bombelli, P., Howe, C.J., Merchant, S.S., Davies, J.M. \& Smith, A.G. 2016. Exploiting algal NADPH oxidase for biophotovoltaic energy. Plant Biotechnology Journal 14(1): 22-28.

Baicha, Z., Salar-García, M.J., Ortiz-Martínez, V.M., HernándezFernández, F.J., De los Ríos, A.P., Labjar, N., Lotfi, E. \& Elmahi, M. 2016. A critical review on microalgae as an alternative source for bioenergy production: A promising low cost substrate for microbial fuel cells. Fuel Processing Technology 154: 104-116.

Barber, M.J., Notton, B.A. \& Solomonson, L.P. 1987. Oxidationreduction midpoint potentials of the molybdenum center in spinach NADH: Nitrate reductase. FEBS Letters 213(2): 372-374.

Connolly, J.S., Samuel, E.B. \& Janzen, A.F. 1982. Effects of solvent on the fluorescence properties of bacteriochlorophyll a. Photochemistry and Photobiology 36(5): 565-574.

Cui, Y., Rashid, N., Hu, N., Rehman, M.S.U. \& Han, J.I. 2014. Electricity generation and microalgae cultivation in microbial fuel cell using microalgae-enriched anode and bio-cathode. Energy Conversion and Management 79: 674-680.

Daud, S.M., Daud, W.R.W., Kim, B.H., Somalu, M.R., Bakar, M.H.A., Muchtar, A., Jahim, J.M., Lim, S.S. \& Chang, I.S.
2018. Comparison of performance and ionic concentration gradient of two-chamber microbial fuel cell using ceramic membrane (CM) and cation exchange membrane (CEM) as separators. Electrochimica Acta 259: 365-376.

De Caprariis, B., De Filippis, P., Di Battista, A., Di, L. \& Palma, M.S. 2014. Exoelectrogenic activity of a green microalgae, Chlorella vulgaris, in a bio-photovoltaic cells (bpvs). Chemical Engineering Transactions 38: 523-528.

Dolai, U. 2016. Complete procedure of biochemical reaction in photolysis. Journal of Plant Biochemistry \& Physiology 4(165): $1-2$

EIA 2017. International Energy Outlook 2017. United States: U.S. Energy Information Administration (EIA). Accessed on 11 April 2018.

Ghoreyshi, A.A., Jafary, T., Najafpour, G.D. \& Haghparast, F. 2011. Effect of type and concentration of substrate on power generation in a dual chambered microbial fuel cell. In World Renewable Energy Congress-Sweden 2011: 1174-1181.

Hariz, H.B. \& Takriff, M.S. 2017. Growth and biomass production of native microalgae Chlorella sp., Chlamydomonas sp., and Scenedesmus sp. cultivated in palm oil mill effluent (POME) at different cultivation conditions. Transactions on Science and Technology 4(3): 298-311.

Hariz, H.B., Takriff, M.S., Yasin, N.H.M., Ba-Abbad, M.M. \& Hakimi, N.I.N.M. 2019. Potential of the microalgae-based integrated wastewater treatment and $\mathrm{CO}_{2}$ fixation system to treat palm oil mill effluent (POME) by indigenous microalgae; Scenedesmus sp. and Chlorella sp. Journal of Water Process Engineering 32: 100907.

Hazman, N.A.S., Yasin, N.H.M., Takriff, M.S., Hasan, H.A., Kamarudin, K.F. \& Hakimi, N.I.N.M. 2018. Integrated palm oil mill effluent treatment and $\mathrm{CO}_{2}$ sequestration by microalgae. Sains Malaysiana 47(7): 1455-1464.

Jadhav, D.A., Jain, S.C. \& Ghangrekar, M.M. 2017. Simultaneous wastewater treatment, algal biomass production and electricity generation in clayware microbial carbon capture cells. Applied Biochemistry and Biotechnology 183(3): 1076-1092.

Jafary, T., Daud, W.R.W., Ghasemi, M., Bakar, M.H.A., Sedighi, M., Kim, B.H., Carmona-Martínez, A.A., Jahim, J.M. \& Ismail, M. 2019. Clean hydrogen production in a full biological microbial electrolysis cell. International Journal of Hydrogen Energy 44(58): 30524-30531.

Jones, G.A. \& Warner, K.J. 2016. The 21st century populationenergy-climate nexus. Energy Policy 93: 206-212.

Kim, J., Lee, J.Y., Ahting, C., Johnstone, R. \& Lu, T. 2014. Growth of Chlorella vulgaris using sodium bicarbonate under no mixing condition. Asia Pacific Journal Chemical Engineering 9(4): 604-609.

Lan, J.C.W., Raman, K., Huang, C.M. \& Chang, C.M. 2013. The impact of monochromatic blue and red LED light upon performance of photo microbial fuel cells (PMFCs) using Chlamydomonas reinhardtii transformation $\mathrm{F} 5$ as biocatalyst. Biochemistry Engineering Journal 78: 39-43.

Logan, B.E. 2008. Microbial Fuel Cell. New York: John Wiley $\&$ Sons.

McCormick, A.J., Bombelli, P., Bradley, R.W., Thorne, R., Wenzel, T. \& Howe, C.J. 2015. Biophotovoltaics: 
Oxygenic photosynthetic organisms in the world of bioelectrochemical systems. Energy \& Environmental Science 8(4): 1092-1109.

McCormick, A.J., Bombelli, P., Scott, A.M., Philips, A.J., Smith, A.G., Fisher, A.C. \& Howe, C.J. 2011. Photosynthetic biofilms in pure culture harness solar energy in a mediatorless bio-photovoltaic cell (BPV) system. Energy \& Environmental Science 4(11): 4699-4709.

Mokashi, K., Shetty, V., George, S.A. \& Sibi, G. 2016. Sodium bicarbonate as inorganic carbon source for higher biomass and lipid production integrated carbon capture in Chlorella vulgaris. Achievements in the Life Sciences 10(1): 111-117.

Ng, F.L., Phang, S.M., Periasamy, V., Beardall, J., Yunus, K. \& Fisher, A.C. 2018. Algal biophotovoltaic (BPV) device for generation of bioelectricity using Synechococcus elongatus (Cyanophyta). Journal of Applied Phycology 30(6): 2981-2988.

Ng, F.L., Phang, S.M., Periasamy, V., Yunus, K. \& Fisher, A.C. 2014. Evaluation of algal biofilms on indium tin oxide (ITO) for use in biophotovoltaic platforms based on photosynthetic performance. PLoS ONE 9(5): e97643.

Rahimnejad, M., Bakeri, G., Najafpour, G., Ghasemi, M. \& Oh, S.E. 2014. A review on the effect of proton exchange membranes in microbial fuel cells. Biofuel Resources Journal 1(1): 7-15.

Rodrigues, D.D.S. 2014. Microbial community optimization for electricity generation in microbial fuel cells. Master Thesis. Lisboa, Portugal: Instituto Superior Técnico. (Unpublished).

Rusli, S.F.N., Bakar, M.H.A., Rani, S.J.A., Loh, K.S. \& Mastar, M.S. 2018. Aryl diazonium modification for improved graphite fibre brush in microbial fuel cell. Sains Malaysiana 47(12): 3017-3023.

Saar, K.L., Bombelli, P., Lea-Smith, D.J., Call, T., Aro, E.M., Müller, T., Howe, C.J. \& Knowles, T.P. 2018. Enhancing power density of biophotovoltaics by decoupling storage and power delivery. Nature Energy 3(1): 75-81.

Saratale, R.G., Kuppam, C., Mudhoo, A., Saratale, G.D., Periyasamy, S., Zhen, G., Koók, L., Bakonyi, P., Nemestóthy, N. \& Kumar, G. 2017. Bioelectrochemical systems using microalgae - a concise research update. Chemosphere 177: $35-43$.

Shamsuddin, R.A., Daud, W.R.W., Kim, B.H., Jahim, J.M., Bakar, M.H.A., Noor, W.S.A.M. \& Yunus, R.M. 2018. Electrochemical characterisation of heat-treated metal and non-metal anodes using mud in microbial fuel cell. Sains Malaysiana 47(12): 3043-3049.

Singh, S.P. \& Singh, P. 2015. Effect of temperature and light on the growth of algae species: A review. Renewable Sustainable Energy Review 50: 431-444.

Subhash, G.V., Chandra, R. \& Mohan, S.V. 2013. Microalgae mediated bio-electrocatalytic fuel cell facilitates bioelectricity generation through oxygenic photomixotrophic mechanism. Bioresources Technology 136: 644-653.

Thong, C.H., Phang, S.M., Ng, F.L., Periasamy, V., Ling, T.C., Yunus, K. \& Fisher, A.C. 2019. Effect of different irradiance levels on bioelectricity generation from algal biophotovoltaic (BPV) devices. Energy Science \& Engineering 7(5): 2086-2097.

Ucar, D., Zhang, Y. \& Angelidaki, I. 2017. An overview of electron acceptors in microbial fuel cells. Frontier Microbiology 8: 643.

USGS 2018. Alternative sources of energy - An introduction to fuel cells. In U.S. Geological Survey Bulletin 2179. United States: United States Geological Survey (USGS). Accessed on 11 April 2018.

Wang, X., Feng, Y., Liu, J., Lee, H., Li, C., Li, N. \& Ren, N. 2010. Sequestration of $\mathrm{CO}_{2}$ discharged from anode by algal cathode in microbial carbon capture cells (MCCs). Biosensors Bioelectronics 25(12): 2639-2643.

Yan, C., Zhao, Y., Zheng, Z. \& Luo, X. 2013. Effects of various LED light wavelengths and light intensity supply strategies on synthetic high-strength wastewater purification by Chlorella vulgaris. Biodegradation 24(5): 721-732.

Zhou, M., He, H., Jin, T. \& Wang, H. 2012. Power generation enhancement in novel microbial carbon capture cells with immobilized Chlorella vulgaris. Journal of Power Sources 214: 216-219.

Zou, Y., Pisciotta, J., Billmyre, R.B. \& Baskakov, I.V. 2009. Photosynthetic microbial fuel cells with positive light response. Biotechnology Bioengineering 104(5): 939-946.

Aisyah Nadhirah Juhari, Wan Ramli Wan Daud \& Mimi Hani Abu Bakar*

Fuel Cell Institute

Universiti Kebangsaan Malaysia

43600 UKM Bangi, Selangor Darul Ehsan

Malaysia

Muhd Syazwan Sharani \& Wan Ramli Wan Daud

Faculty of Engineering and Built Environment

Universiti Kebangsaan Malaysia

43600 UKM Bangi, Selangor Darul Ehsan

Malaysia

Tahereh Jafary

Process Engineering Department

International Maritime College, Sohar

Oman

*Corresponding author; email: mimihani@ukm.edu.my

Received: 17 August 2020

Accepted: 11 September 2020 